\title{
Effect of Dietary Crude Protein Concentration on Ruminal Nitrogen Metabolism in Lactating Dairy Cows ${ }^{1}$
}

\author{
J. J. Olmos Colmenero*2 and G. A. Broderick ${ }^{3}$ \\ *Department of Dairy Science, University of Wisconsin, Madison 53706 \\ †Agricultural Research Service, USDA US Dairy Forage Research Center, 1925 Linden Drive West, Madison, WI 53706
}

\begin{abstract}
Ten lactating Holstein cows fitted with ruminal cannulas that were part of a larger feeding trial were blocked by days in milk into 2 groups and then randomly assigned to 1 of 2 incomplete $5 \times 5$ Latin squares. Diets contained [dry matter (DM) basis] $25 \%$ alfalfa silage, $25 \%$ corn silage, and $50 \%$ concentrate. Rolled high-moisture shelled corn was replaced with solventextracted soybean meal to increase crude protein (CP) from $13.5 \%$ to $15.0,16.5,17.9$, and $19.4 \%$ of DM. Each of the 4 experimental periods lasted $28 \mathrm{~d}$ with data and sample collection performed during the last $8 \mathrm{~d}$. Digesta samples were collected from the omasum to quantify the ruminal outflow of different $\mathrm{N}$ fractions. Intake of DM was not affected but showed a quadratic trend with maxima of $23.9 \mathrm{~kg} / \mathrm{d}$ at $16.5 \% \mathrm{CP}$. Ruminal outflow of total bacterial nonammonia $\mathrm{N}$ (NAN) was not different among diets but a significant linear effect of dietary $\mathrm{CP}$ was detected for this variable. Bacterial efficiency ( $\mathrm{g}$ of total bacterial NAN flow $/ \mathrm{kg}$ of organic matter truly digested in the rumen) and omasal flows of dietary NAN and total NAN also showed positive linear responses to dietary CP. Total NAN flow increased from $574 \mathrm{~g} / \mathrm{d}$ at $13.5 \% \mathrm{CP}$ to $688 \mathrm{~g} / \mathrm{d}$ at $16.5 \% \mathrm{CP}$ but did not increase further with the feeding of more CP. Under the conditions of this study, $16.5 \%$ of dietary CP appeared to be sufficient for maximal ruminal outflow of total bacterial NAN and total NAN.
\end{abstract}

Key words: dietary crude protein, bacterial protein formation, omasal $\mathrm{N}$ flow

\section{INTRODUCTION}

Sources of MP include feed protein that escapes rumen degradation and microbial protein synthesized in

\footnotetext{
Received June 6, 2005.

Accepted August 23, 2005.

${ }^{1}$ Mention of any trademark or proprietary product in this paper does not constitute a guarantee or warranty of the product by the USDA or the Agricultural Research Service and does not imply its approval to the exclusion of other products that also may be suitable.

${ }^{2}$ Present address: Centro Universitario de los Altos, Universidad de Guadalajara, Carretera a Yahualica Km. 7.5, Tepatitlan de Morelos, Jalisco, Mexico CP 47600.

${ }^{3}$ Corresponding author: gbroderi@wisc.edu
}

the rumen (NRC, 2001). Many attempts have been made to substitute high RUP sources in dairy diets to increase the flow of MP to the small intestine. However, after reviewing reports from 15 in vivo studies, Santos et al. (1998) concluded that replacement of soybean meal, the most common protein source fed to dairy cows in the United States, with high RUP sources did not increase the duodenal flows of total NAN, essential AA, Lys, or Met. Instead, supplementation with high RUP sources decreased microbial NAN flow to the duodenum in $76 \%$ of the studies. Flow of total NAN was not affected because the increase in dietary NAN flow generally compensated for lower microbial NAN flow.

Microbial protein contributes more than $60 \%$ of the NAN that leaves the rumen in dairy cows (Korhonen et al., 2002; Reynal et al., 2003), its digestibility in the small intestine averages $80 \%$, and it contains Lys and Met, the most limiting AA for milk production, in about the same proportion as found in milk (NRC, 2001). Cunningham et al. (1996), Leonardi et al. (2003), and Broderick (2003) observed no effect on milk and protein yield of dairy cows when soy protein supplementation increased dietary CP from 16.5 to $18.5 \%$, from 16.1 to $18.9 \%$, and from 16.7 to $18.4 \%$. These findings are consistent with the pattern shown in the much larger databases of NRC (2001) and in the recent reviews of Huhtanen and Shingfield (2005) and Ipharraguerre and Clark (2005), indicating that milk yield increased at a substantially lower rate at higher dietary CP than at lower dietary CP concentrations. These reports suggested that milk yield was not increased because microbial protein yield was not improved above about $16.5 \% \mathrm{CP}$.

Therefore, the objective of this study was to determine the optimum CP content of the diet to maximize microbial protein formation and ruminal outflow of NAN in dairy cows fed diets formulated from typical US ingredients with solvent-extracted soybean meal (SSBM) as the principal protein supplement.

\section{MATERIALS AND METHODS}

\section{Experimental Procedure}

As part of a larger feeding trial (Olmos Colmenero and Broderick, 2006), 10 lactating Holstein cows fitted 
Table 1. Composition of diets

\begin{tabular}{|c|c|c|c|c|c|}
\hline \multirow[b]{2}{*}{ Item $^{1}$} & \multicolumn{5}{|c|}{ Diets (\% CP) } \\
\hline & $\begin{array}{l}\text { A } \\
(13.5)\end{array}$ & $\begin{array}{l}\text { B } \\
(15.0)\end{array}$ & $\begin{array}{l}\mathrm{C} \\
(16.5)\end{array}$ & $\begin{array}{l}\mathrm{D} \\
(17.9)\end{array}$ & $\begin{array}{l}\mathrm{E} \\
(19.4)\end{array}$ \\
\hline & \multicolumn{5}{|c|}{$\longrightarrow(\%$ of $\mathrm{DM})$} \\
\hline Alfalfa silage & 25.0 & 25.0 & 25.0 & 25.0 & 25.0 \\
\hline Corn silage & 25.0 & 25.0 & 25.0 & 25.0 & 25.0 \\
\hline RHMSC & 44.0 & 40.6 & 37.2 & 33.8 & 30.4 \\
\hline SSBM & 2.4 & 5.8 & 9.2 & 12.6 & 16.0 \\
\hline Roasted soybeans & 2.5 & 2.5 & 2.5 & 2.5 & 2.5 \\
\hline Sodium bicarbonate & 0.6 & 0.6 & 0.6 & 0.6 & 0.6 \\
\hline Salt & 0.2 & 0.2 & 0.2 & 0.2 & 0.2 \\
\hline Dicalcium phosphate & 0.2 & 0.2 & 0.2 & 0.2 & 0.2 \\
\hline Vitamin-mineral premix ${ }^{2}$ & 0.1 & 0.1 & 0.1 & 0.1 & 0.1 \\
\hline \multicolumn{6}{|l|}{ Chemical composition } \\
\hline $\mathrm{DM}, \%$ & 54.1 & 54.3 & 54.6 & 54.9 & 55.2 \\
\hline $\mathrm{CP}, \%$ of $\mathrm{DM}$ & 13.5 & 15.0 & 16.5 & 17.9 & 19.4 \\
\hline Ash, \% of DM & 5.97 & 6.16 & 6.35 & 6.54 & 6.73 \\
\hline NDF, \% of DM & 22.4 & 22.4 & 22.4 & 22.4 & 22.4 \\
\hline $\mathrm{ADF}, \%$ of $\mathrm{DM}$ & 12.4 & 12.5 & 12.6 & 12.7 & 12.8 \\
\hline Neutral detergent insoluble CP, \% of DM & 0.50 & 0.55 & 0.59 & 0.63 & 0.68 \\
\hline $\mathrm{RDP}^{3} \%$ of $\mathrm{DM}$ & 9.3 & 10.2 & 11.0 & 11.9 & 12.7 \\
\hline $\mathrm{RUP}^{3} \%$ of DM & 4.2 & 4.8 & 5.5 & 6.0 & 6.7 \\
\hline $\mathrm{NFC}^{3} \%$ of $\mathrm{DM}$ & 55.0 & 53.5 & 51.9 & 50.4 & 48.8 \\
\hline Discounted total digestible nutrients, ${ }^{3} \%$ of DM & 66.2 & 65.9 & 65.5 & 65.8 & 65.4 \\
\hline $\mathrm{NE}_{\mathrm{L}},{ }^{3} \mathrm{Mcal} / \mathrm{kg}$ of $\mathrm{DM}$ & 1.59 & 1.59 & 1.60 & 1.62 & 1.62 \\
\hline
\end{tabular}

with ruminal cannulas were blocked by DIM into 2 groups with means (SD) of 78 (36) and 176 (47) DIM, $3.0(2.3)$ and 2.8 (1.9) parity, $536(53)$ and $580(96) \mathrm{kg}$ of BW, and 39 (8) and 36 (5) $\mathrm{kg}$ of milk/d, and then randomly assigned to 1 of 2 diet sequences in incomplete $5 \times 5$ Latin squares ( 5 diets and 4 periods). The duration of each experimental period was $28 \mathrm{~d}$ with the last $8 \mathrm{~d}$ used for collection of data and samples. Cows were held in tie stalls for the duration of the experiment, had free access to water, and were weighed on 3 consecutive days at the beginning and at the end of each period. Recombinant bST was injected (500 mg of Posilac; Monsanto, St. Louis, MO) every $14 \mathrm{~d}$ into all animals starting on the first day of the experiment. Animal care and experimental procedures met the requirements of the Institutional Animal Care and Use Committee of the UW-Madison (Research Animal Resources Center protocol \# A-07-3400-A00286). During period 3, one cow was removed from the experiment due to health problems unrelated to the experiment.

Experimental diets were fed as TMR and contained (DM basis) $25 \%$ alfalfa silage, $25 \%$ corn silage, and $50 \%$ of a concentrate formulated principally from rolled high-moisture shelled corn, SSBM, and roasted soybeans. Dietary CP was increased in increments of approximately 1.5 percentage units from 13.5 to $19.4 \%$, by replacing rolled-high moisture shelled corn with SSBM (Table 1). Cows were fed once daily at about $1600 \mathrm{~h}$ and feed offered was adjusted daily to yield 5 to $10 \%$ orts. Samples of individual feeds and orts (about $0.5 \mathrm{~kg}$ ) were taken daily and stored at $-20^{\circ} \mathrm{C}$. Weekly composite samples from feeds and orts were dried at $60^{\circ} \mathrm{C}$ for 48 $\mathrm{h}$ and the as-fed composition of the diets was adjusted every week. Weekly feed composites were ground through a 1-mm screen (Wiley mill, Arthur H. Thomas, Philadelphia, PA), and analyzed for DM at $105^{\circ} \mathrm{C}$ (AOAC, 1980) and for total N (Leco 2000; Leco Instruments, Inc., St. Joseph, MI) to adjust diets to the desired $\mathrm{CP}$ content (total $\mathrm{N} \times 6.25$ ) every week. Intake of DM was corrected for orts, and recorded daily throughout the experiment. Feed samples were analyzed sequentially for NDF and ADF (Van Soest et al., 1991) using heat-stable amylase and sodium sulfite (Hintz et al., 1995) in an Ankom Fiber Analyzer (Ankom Technology Corp., Fairport, NY). The N content of NDF residues was analyzed by combustion assay (Leco Instruments Inc.). Ash and OM contents of feeds were also measured (AOAC, 1980). Compositions of the diets reported in Table 1 are averages from wk 3 and wk 4 of all 4 experimental periods. Other details of the feeding study are described in the companion paper (Olmos Colmenero and Broderick, 2006). 
Extent of ruminal digestion and flows at the omasum of dietary nutrients were estimated using CoEDTA (Uden et al., 1980), Yb-chloride (Siddons et al., 1985), and indigestible NDF (Huhtanen et al., 1994) as markers for, respectively, the fluid phase (FP), small-particle phase (SP), and large-particle phase (LP) of digesta. The CoEDTA and Yb-chloride markers were dissolved in distilled water, and continuously infused into the rumen through the cannula of each cow using a syringe pump (model 33, Harvard Apparatus Inc., Holliston, MA) from d 21 to 26 of each period at a rate of $2.3 \mathrm{~g} / \mathrm{d}$ of $\mathrm{Co}$ and $3.1 \mathrm{~g} / \mathrm{d}$ of $\mathrm{Yb}$ per cow per day. The microbial marker, $\left(\mathrm{NH}_{4}\right)_{2} \mathrm{SO}_{4}$, enriched to 10 atom percent excess ${ }^{15} \mathrm{~N}$ (Isotec, Miamisburg, OH), was infused in the same mixture at a rate of $0.22 \mathrm{~g}$ of ${ }^{15} \mathrm{~N} / \mathrm{cow}$ per day. Prior to infusion of markers, a sample of ruminal contents was collected from each cow to determine the background ${ }^{15} \mathrm{~N}$, stored at $-20^{\circ} \mathrm{C}$, freeze-dried, and ground through a $0.5-\mathrm{mm}$ screen in an Udy Cyclone Sample mill (Udy Corporation, Fort Collins, CO).

Digesta samples were collected from the omasal canal as described by Reynal et al. (2003). Each period, 200$\mathrm{mL}$ spot samples were collected and composited over 3 d (d 24 at 0000, 0200, 0400 and $0600 \mathrm{~h} ; \mathrm{d} 25$ at 0800, 1000,1200 , and $1400 \mathrm{~h}$; and $\mathrm{d} 26$ at 1600, 1800, 2000, and $2200 \mathrm{~h}$ ) to represent the 24 -h feeding cycle. After collection, samples were frozen immediately, and stored at $-20^{\circ} \mathrm{C}$ for later analysis. Digesta samples were separated into FP, SP, and LP as described by Reynal and Broderick (2005). After separation, FP, SP, and LP were frozen, freeze-dried, ground through 1-mm screen (Wiley mill), and then analyzed for $\mathrm{Co}$ and $\mathrm{Yb}$ by direct current plasma emission spectroscopy (SpectraSpan V, Fison Instruments, Valencia, CA) as described by Combs and Satter (1992). Samples of TMR from the fourth week of each period, as well as SP and LP samples, were analyzed for indigestible NDF according to the procedure of Huhtanen et al. (1994) using $5 \times 10$ $\mathrm{cm}$ Dacron bags with a pore size of $6 \mu \mathrm{m}$ (Sefar America Inc, Kansas City, MO). The triple-marker approach of France and Siddons (1986) was applied to compute the amounts of DM from each digesta phase required to reconstitute the theoretical omasal true digesta (OTD) flowing out of the rumen. Based on marker concentration and the triple-marker approach, DM from SP and LP were also mixed to obtain a 2 -g sample $(\mathbf{S P}+\mathbf{L P})$ that was reground through a $0.5-\mathrm{mm}$ screen in the Udy mill for later analysis.

An extra 100-mL sample of omasal digesta was collected at each sampling time, kept on ice, and composited ( $400 \mathrm{~mL} /$ cow each sampling day) for bacterial isolation. At the end of each sampling day, samples were squeezed through 2 layers of cheesecloth and the particles retained on the cheesecloth were washed with 400
$\mathrm{mL}$ of $0.85 \%$ (wt/vol) $\mathrm{NaCl}$ solution. The first and second filtrates were combined and centrifuged for $5 \mathrm{~min}$ at $1,000 \times g$ at $4^{\circ} \mathrm{C}$ to sediment the protozoa and small feed particles. Then, about $400 \mathrm{~mL}$ of the resulting supernatants were centrifuged for $30 \mathrm{~min}$ at $11,325 \times$ $g$ at $4^{\circ} \mathrm{C}$ to obtain a pellet of fluid-associated bacteria (FAB). Pellets from the first centrifugation (protozoa and small feed particles) plus particles retained on the cheesecloth were mixed in $400 \mathrm{~mL}$ of $0.85 \%$ (wt/vol) $\mathrm{NaCl}$ solution containing $1 \%$ (vol/vol) Tween 80, blended for $20 \mathrm{~s}$ in a commercial blender (model 51BL32, Waring Commercial, Torrington, CT), and held for $24 \mathrm{~h}$ at $4^{\circ} \mathrm{C}$. These samples were then squeezed through 2 layers of cheesecloth, the filtrate centrifuged for $5 \mathrm{~min}$ at $1,000 \times g$ at $4^{\circ} \mathrm{C}$, and the pellet discarded. The supernatants were recentrifuged for $30 \mathrm{~min}$ at $11,325 \times g$ at $4^{\circ} \mathrm{C}$ to obtain a pellet of particle-associated bacteria (PAB). Both FAB and PAB pellets were washed once by resuspending them in $100 \mathrm{~mL}$ of McDougalls' buffer, and centrifuging again for $30 \mathrm{~min}$ at $11,325 \times g$ at $4^{\circ} \mathrm{C}$. Pellets were then stored at $-20^{\circ} \mathrm{C}$ for later analysis.

At the third sampling time each sampling day, 500 $\mathrm{mL}$ of omasal digesta was collected from each cow for isolation of protozoa. Samples were immediately squeezed through 2 layers of cheesecloth, and the retained particles washed with $500 \mathrm{~mL}$ of McDougalls' buffer $\left(39^{\circ} \mathrm{C}\right)$ containing $5.0 \mathrm{~g}$ of glucose and $0.5 \mathrm{~g}$ of cysteine-HCl/L. The first filtrate plus the wash filtrate were combined in a separatory funnel, placed in a $39^{\circ} \mathrm{C}$ water bath for $45 \mathrm{~min}$, and the protozoa carefully drawn off. Protozoal samples were then layered on top of 20 $\mathrm{mL}$ of $30 \%$ (wt/vol) sucrose solution in $50-\mathrm{mL}$ centrifuge tubes and centrifuged at $150 \times \mathrm{g}$ for $5 \mathrm{~min}$ at $4^{\circ} \mathrm{C}$. The resulting protozoal pellets were washed 3 times with 5 $\mathrm{mL}$ of $0.85 \%$ (wt/vol) $\mathrm{NaCl}$ solution, centrifuged for 5 $\min$ at $1,239 \times g$ at $4^{\circ} \mathrm{C}$, and stored at $-20^{\circ} \mathrm{C}$.

All FAB, PAB, and protozoal pellets ( 3 of each per cow per period) were freeze-dried, ground with a mortar and pestle, and pooled by weight into single FAB, PAB, and protozoa composite samples per cow per period.

The OTD, and composite FAB, PAB, and protozoal samples were analyzed for $\mathrm{DM}\left(105^{\circ} \mathrm{C}\right)$, ash, and $\mathrm{OM}$ contents (AOAC, 1980). The OTD samples were also analyzed for total N (Leco 2000, Leco Instruments, Inc.), and sequentially for NDF and ADF (Van Soest et al., 1991) using heat-stable amylase and sodium sulfite (Hintz et al., 1995) in an Ankom Fiber Analyzer (Ankom Technology Corp.). The N content of these NDF and $\mathrm{ADF}$ residues (NDIN and ADIN) was determined by a combustion assay (Leco Instruments Inc.).

A 0.5-g sample of OTD from each cow was extracted in $10 \mathrm{~mL}$ of citrate buffer $(77.5 \mathrm{~m} M$ adjusted to $\mathrm{pH} 2.2$ with $\mathrm{HCl}$ ) for $30 \mathrm{~min}$ at $39^{\circ} \mathrm{C}$, and centrifuged at 15,000 
$\times g$ at $4^{\circ} \mathrm{C}$ for $15 \mathrm{~min}$. The resulting supernatants were then analyzed for free $\mathrm{AA}$ and $\mathrm{NH}_{3}$ (Broderick et al., 2004). Subsamples of ruminal contents (freeze-dried and ground), FAB, PAB, protozoa, $\mathrm{FP}$, and $\mathrm{SP}+\mathrm{LP}$ were weighed in duplicate into tin caps to provide about 100 $\mu \mathrm{g}$ of N. Subsamples in the tin caps then were treated with $50 \mu \mathrm{L}$ of $\mathrm{K}_{2} \mathrm{CO}_{3}$ solution $(10 \mathrm{~g} / \mathrm{L}$, wt/vol), heated overnight in a $60^{\circ} \mathrm{C}$ oven to remove $\mathrm{NH}_{3}$ (Nagel and Broderick, 1992), and then analyzed for total $\mathrm{N}$ and ${ }^{15} \mathrm{~N}$ (UC-Davis Stable Isotope Facility, Davis, CA). Enrichment of ${ }^{15} \mathrm{~N}$ in omasal samples (FAB, PAB, protozoa, $\mathrm{FP}$, and $\mathrm{SP}+\mathrm{LP})$ was determined by subtracting the background ${ }^{15} \mathrm{~N}$ content in rumen samples, collected before infusion of ${ }^{15} \mathrm{~N}$ (average of $0.368 \%$ of total $\mathrm{N}$ ), from the ${ }^{15} \mathrm{~N}$ content of omasal samples. The ruminal outflows of $\mathrm{N}$ fractions and RDP supply were computed as follows:

$$
\begin{gathered}
\text { FAB NAN flow }(\mathrm{g} / \mathrm{d})= \\
{\left[\mathrm{FP}^{15} \mathrm{~N} \text { enrichment } / \text { FAB }{ }^{15} \mathrm{~N} \text { enrichment }\right]} \\
\times \text { FP NAN flow }(\mathrm{g} / \mathrm{d}) \\
\text { PAB NAN flow }(\mathrm{g} / \mathrm{d})= \\
{\left[\mathrm{SP}+\mathrm{LP}{ }^{15} \mathrm{~N} \text { enrichment } / \text { PAB }{ }^{15} \mathrm{~N} \text { enrichment }\right]} \\
\times \mathrm{SP}+\text { LP NAN flow }(\mathrm{g} / \mathrm{d}) \\
\text { Total bacterial NAN flow }(\mathrm{g} / \mathrm{d})= \\
\text { FAB NAN flow }(\mathrm{g} / \mathrm{d})+\text { PAB NAN flow }(\mathrm{g} / \mathrm{d}) \\
\text { Dietary NAN flow }(\mathrm{g} / \mathrm{day})= \\
\text { Total NAN flow in OTD }(\mathrm{g} / \mathrm{d}) \\
- \text { Total bacterial NAN flow }(\mathrm{g} / \mathrm{d}) \\
\text { RDP supply }(\mathrm{g} / \mathrm{d})= \\
\text { Total CP intake }(\mathrm{g} / \mathrm{d})-[\text { Dietary NAN flow }(\mathrm{g} / \mathrm{d}) \times 6.25]
\end{gathered}
$$

where the flows of the FP NAN, SP+LP NAN, and total NAN in OTD were determined using the triple-marker technique (Reynal and Broderick, 2005).

\section{Statistical Analyses}

Data were analyzed as a Latin square design using the mixed procedures of SAS (SAS Institute, 1999). Model sums of squares were separated into overall mean, cow (within square), square, period, treatment (effect of diet), and square $\times$ treatment interaction. All variables were considered fixed, except cow (within square) and overall error, which were considered random. The interaction term square $\times$ treatment was removed from the model when $P \geq 0.25$. Linear and qua- dratic effects of treatments also were estimated. Significance was declared at $P \leq 0.05$. Variables that showed $P \leq 0.10$ for quadratic effects were regressed on dietary $\mathrm{CP}$ concentration using the mixed procedures of SAS (SAS Institute, 1999) to obtain the intercept and the linear and quadratic coefficients of the quadratic regression model. These equations were solved for the concentration of dietary $\mathrm{CP}$ at which these variables reached their maximal responses.

\section{RESULTS AND DISCUSSION}

Results of milk production, rumen metabolites, total tract digestibility, and $\mathrm{N}$ excretion of all cows as part of the larger feeding study are reported in the companion paper (Olmos Colmenero and Broderick, 2006).

\section{Intake and Ruminal Digestibility}

Intake of DM, OM, and NDF showed quadratic trends ( $P=0.08, P=0.08$, and $P=0.10$, respectively) but intake of $\mathrm{ADF}$ was not affected by increasing levels of dietary CP (Table 2). As expected, intake of CP increased linearly with dietary CP. Apparent ruminal digestibility (\% of intake) and omasal flow of DM, OM, and NDF, and OM truly digested in the rumen were not affected by diet (Table 2). However, ADF apparently digested in the rumen, and omasal flow and apparent ruminal digestibility of $\mathrm{CP}$ increased linearly with dietary CP. Amount of DM and OM apparently digested in the rumen showed quadratic trends $(P=0.07$ and $P=0.06$, respectively) and amount of NDF digested and apparent ADF digestibility (\% of intake) in the rumen showed linear trends $(P=0.07$ and $P=0.09$, respectively) in response to increasing $\mathrm{CP}$ in the diet.

The linear increases in the concentrations of both isobutyrate and isovalerate observed in this trial (Olmos Colmenero and Broderick, 2006) might have contributed to the linear responses in ruminal fiber digestion (Misra and Thakur, 2001), which in turn may have resulted in the numerical improvements in the intakes of DM, OM, NDF, and ADF when dietary $\mathrm{CP}$ increased from 13.5 to $16.5 \%$. Cunningham et al. (1996) observed a linear increase in NDF and ADF intake when increasing CP content of the diet from 14.4 to 16.4 and $18.4 \%$; however, ruminal digestibility of $\mathrm{OM}$, $\mathrm{NDF}$, and $\mathrm{ADF}$ was not affected. Christensen et al. (1993) did not detect any improvement in intake or apparent ruminal digestibility of $\mathrm{OM}, \mathrm{NDF}$, and $\mathrm{ADF}$ when they increased dietary CP from 16.4 to $19.6 \%$ of DM.

\section{Omasal Flow of Nitrogen Fractions}

Chemical composition of ruminal microbes is presented in Table 3. Content of OM in FAB, PAB, and 
Table 2. Effect of dietary CP content on intake, omasal flow, and apparent ruminal digestibility of nutrients

\begin{tabular}{|c|c|c|c|c|c|c|c|c|c|}
\hline \multirow[b]{2}{*}{ Item } & \multicolumn{5}{|c|}{ Dietary CP, \% of DM } & \multirow[b]{2}{*}{$\mathrm{SE}^{2}$} & \multicolumn{3}{|c|}{$P>\mathrm{F}^{1}$} \\
\hline & 13.5 & 15.0 & 16.5 & 17.9 & 19.4 & & $\mathrm{CP}$ & $\mathrm{L}$ & $\mathrm{Q}$ \\
\hline Ruminal pH & 6.42 & 6.41 & 6.39 & 6.40 & 6.44 & 0.06 & 0.93 & 0.86 & 0.34 \\
\hline DM & 21.9 & 22.9 & 23.8 & 23.5 & 22.6 & 1.1 & 0.44 & 0.34 & 0.08 \\
\hline $\mathrm{OM}$ & 20.7 & 21.6 & 22.3 & 22.1 & 21.1 & 1.0 & 0.48 & 0.45 & 0.08 \\
\hline $\mathrm{CP}$ & $2.97^{\mathrm{d}}$ & $3.48^{\mathrm{c}}$ & $3.95^{\mathrm{b}}$ & $4.25^{\mathrm{ab}}$ & $4.46^{\mathrm{a}}$ & 0.20 & $<0.01$ & $<0.01$ & 0.16 \\
\hline NDF & 4.81 & 5.04 & 5.25 & 5.15 & 4.98 & 0.25 & 0.46 & 0.33 & 0.10 \\
\hline $\mathrm{DM}$ & 7.86 & 8.76 & 8.55 & 8.46 & 8.01 & 0.61 & 0.42 & 0.94 & 0.07 \\
\hline $\mathrm{OM}$ & 9.3 & 10.1 & 10.0 & 9.8 & 9.3 & 0.6 & 0.42 & 0.81 & 0.06 \\
\hline $\mathrm{CP}$ & $-0.68^{\mathrm{c}}$ & $-0.30^{\mathrm{b}}$ & $-0.44^{\mathrm{bc}}$ & $-0.16^{\mathrm{ab}}$ & $0.03^{\mathrm{a}}$ & 0.15 & $<0.01$ & $<0.01$ & 1.00 \\
\hline NDF & 1.46 & 1.74 & 1.66 & 1.65 & 1.85 & 0.14 & 0.20 & 0.07 & 0.78 \\
\hline $\mathrm{ADF}$ & 0.70 & 0.84 & 0.87 & 0.84 & 0.99 & 0.09 & 0.26 & 0.04 & 0.91 \\
\hline \multicolumn{10}{|c|}{ Ruminal digestibility, $\%$ of intake } \\
\hline DM & 35.6 & 38.2 & 36.1 & 35.8 & 36.0 & 1.9 & 0.58 & 0.68 & 0.48 \\
\hline OMTDR, ${ }^{3} \mathrm{~kg} / \mathrm{d}$ & 14.0 & 14.6 & 15.0 & 14.8 & 14.3 & 0.8 & 0.70 & 0.62 & 0.15 \\
\hline OMTDR, $4 \%$ of intake & 67.5 & 67.7 & 67.0 & 66.7 & 67.6 & 1.0 & 0.89 & 0.71 & 0.56 \\
\hline \multicolumn{10}{|l|}{ Omasal flow, kg/d } \\
\hline DM & 14.0 & 14.2 & 15.2 & 15.1 & 14.6 & 0.8 & 0.50 & 0.24 & 0.27 \\
\hline $\mathrm{OM}$ & 11.3 & 11.5 & 12.4 & 12.3 & 11.9 & 0.6 & 0.49 & 0.21 & 0.26 \\
\hline $\mathrm{CP}$ & $3.65^{\mathrm{b}}$ & $3.78^{\mathrm{b}}$ & $4.38^{\mathrm{a}}$ & $4.40^{\mathrm{a}}$ & $4.44^{\mathrm{a}}$ & 0.26 & 0.02 & $<0.01$ & 0.35 \\
\hline $\mathrm{NDF}$ & 3.37 & 3.31 & 3.59 & 3.49 & 3.16 & 0.17 & 0.31 & 0.73 & 0.12 \\
\hline $\mathrm{ADF}$ & 2.00 & 1.99 & 2.09 & 2.08 & 1.90 & 0.12 & 0.72 & 0.81 & 0.25 \\
\hline
\end{tabular}

${ }^{\mathrm{a}-\mathrm{d}}$ Means in the same row without common superscripts differ $(P<0.05)$.

${ }^{1}$ Probability of a significant effect of dietary CP content or of a linear (L) or quadratic (Q) effect of dietary CP content.

${ }^{2}$ Standard error of the least squares means.

${ }^{3}$ Organic matter truly digested in the rumen [OMTDR, kg/d = total OM flow (kg/d) - bacterial OM flow (kg/d)].

${ }^{4}$ Organic matter truly digested in the rumen $\{$ OMTDR, $\%=[$ OMTDR $(\mathrm{kg} / \mathrm{d}) / \mathrm{OM}$ intake $(\mathrm{kg} / \mathrm{d})] \times 100\}$.

Table 3. Effect of dietary CP content on microbial composition ${ }^{1}$

\begin{tabular}{|c|c|c|c|c|c|c|c|c|c|}
\hline \multirow[b]{2}{*}{ Item } & \multicolumn{5}{|c|}{ Dietary CP, \% of DM } & \multirow[b]{2}{*}{$\mathrm{SE}^{3}$} & \multicolumn{3}{|c|}{$P>\mathrm{F}^{2}$} \\
\hline & 13.5 & 15.0 & 16.5 & 17.9 & 19.4 & & $\mathrm{CP}$ & $\mathrm{L}$ & $\mathrm{Q}$ \\
\hline \multicolumn{10}{|c|}{$\mathrm{OM}, \%$ of $\mathrm{DM}$} \\
\hline FAB & 78.5 & 79.0 & 79.0 & 78.9 & 78.7 & 0.7 & 0.96 & 0.69 & 0.56 \\
\hline РAB & 84.8 & 85.0 & 84.9 & 84.8 & 84.5 & 0.3 & 0.64 & 0.43 & 0.32 \\
\hline Protozoa & 96.1 & 96.1 & 96.0 & 95.6 & 96.3 & 0.6 & 0.83 & 0.85 & 0.49 \\
\hline \multicolumn{10}{|c|}{ NAN, \% of DM } \\
\hline $\mathrm{FAB}$ & $7.09^{\mathrm{c}}$ & $7.33^{\mathrm{bc}}$ & $7.64^{\mathrm{ab}}$ & $7.85^{\mathrm{a}}$ & $7.79^{\mathrm{a}}$ & 0.14 & $<0.01$ & $<0.01$ & 0.22 \\
\hline PAB & $7.77^{\mathrm{bc}}$ & $7.66^{\mathrm{c}}$ & $7.94^{\mathrm{ab}}$ & $7.99^{\mathrm{a}}$ & $7.95^{\mathrm{ab}}$ & 0.09 & 0.02 & $<0.01$ & 0.86 \\
\hline Protozoa & 2.23 & 2.23 & 2.52 & 2.45 & 2.32 & 0.16 & 0.28 & 0.18 & 0.41 \\
\hline \multicolumn{10}{|c|}{${ }^{15} \mathrm{~N}$, atom $\%$ excess } \\
\hline FAB & $0.053^{\mathrm{a}}$ & $0.047^{\mathrm{b}}$ & $0.041^{\mathrm{c}}$ & $0.036^{\mathrm{c}}$ & $0.039^{c}$ & 0.002 & $<0.01$ & $<0.01$ & 0.03 \\
\hline PAB & $0.049^{\mathrm{a}}$ & $0.044^{\mathrm{b}}$ & $0.038^{\mathrm{c}}$ & $0.033^{\mathrm{c}}$ & $0.035^{\mathrm{c}}$ & 0.002 & $<0.01$ & $<0.01$ & 0.05 \\
\hline Protozoa & $0.046^{\mathrm{a}}$ & $0.039^{b}$ & $0.036^{\mathrm{c}}$ & $0.030^{\mathrm{d}}$ & $0.034^{\text {cd }}$ & 0.002 & $<0.01$ & $<0.01$ & $<0.01$ \\
\hline
\end{tabular}

${ }^{\mathrm{a}-\mathrm{d}}$ Means in the same row without common superscripts differ $(P<0.05)$.

${ }^{1} \mathrm{FAB}=$ Fluid-associated bacteria, $\mathrm{PAB}=$ particle-associated bacteria.

${ }^{2}$ Probability of a significant effect of dietary CP content or of a linear (L) or quadratic (Q) effect of dietary CP content.

${ }^{3}$ Standard error of the least squares means. 
protozoa did not change in response to dietary $\mathrm{CP}$ and was on average 6.0 percentage units higher in $\mathrm{PAB}$ $(85 \%)$ than in FAB $(79 \%)$. The NAN content of both FAB and $\mathrm{PAB}$ increased linearly $(P<0.01)$, whereas that of protozoa was not significantly affected. Surprisingly, the NAN content of protozoa was very low, averaging $2.35 \%$ of DM. The ${ }^{15} \mathrm{~N}$ enrichment of all microbial pools showed linear and quadratic responses to dietary $\mathrm{CP}$. The highest ${ }^{15} \mathrm{~N}$ enrichment of microbes was observed with the lowest CP level and the lowest enrichments were found at the 2 (protozoa) and 3 (FAB, PAB) highest CP levels.

Differences in chemical composition of different microbial fractions (FAB and PAB) have been reported previously (Craig et al., 1987; Martin et al., 1994). Therefore, collection of samples from the different bacterial pools is necessary to quantify bacterial protein flow. The decline in microbial ${ }^{15} \mathrm{~N}$ enrichment with higher $\mathrm{CP}$ diets in this trial may have occurred because ${ }^{15} \mathrm{~N}$ enrichment of the $\mathrm{NH}_{3}$ may have been diluted from increasing ruminal $\mathrm{NH}_{3}$ formation with greater protein degradation as the dietary $\mathrm{CP}$ increased. The ${ }^{15} \mathrm{~N}$ enrichment of protozoa occurs indirectly through bacterial engulfment (Broderick and Merchen, 1992). Therefore, any change in bacterial ${ }^{15} \mathrm{~N}$ enrichment should be reflected in the ${ }^{15} \mathrm{~N}$ enrichment of protozoa. On average, ${ }^{15} \mathrm{~N}$ enrichment of protozoa was, respectively, 86 and 93\% of that in FAB and PAB. Stokes et al. (1991) and Martin et al. (1994) reported that the average $\mathrm{N}$ content in protozoa was higher than $5.0 \%$ of DM. The relatively low NAN content in protozoa observed in this study might have resulted from contamination of protozoal samples with low $\mathrm{N}$ feed particles or from carbon incorporation from the sucrose solution used in their isolation.

Omasal flows of $\mathrm{N}$ fractions are summarized in Table 4. As $\mathrm{N}$ intake increased linearly $(P<0.01)$ from 476 $\mathrm{g} / \mathrm{d}$ at $13.5 \% \mathrm{CP}$ to $714 \mathrm{~g} / \mathrm{d}$ at $19.4 \% \mathrm{CP}$, there were linear increases $(P<0.01)$ in flow of total $\mathrm{N}, \mathrm{NH}_{3} \mathrm{~N}$, and free AA N. However, flows of these $3 \mathrm{~N}$ fractions were not significantly different among the 3 highest dietary CP levels. Although ruminal outflow of total NAN also showed a linear response to $\mathrm{CP}$, there were substantial differences in the change in NAN flow among dietary CP increments. Flow of NAN increased $19 \mathrm{~g} / \mathrm{d}$ from 13.5 to $15.0 \% \mathrm{CP}$, but the largest increase $(95 \mathrm{~g} / \mathrm{d})$ was observed when CP changed from 15.0 to $16.5 \%$ due to large increases in both dietary and bacterial NAN flow. Further increments in CP supplementation did not result in higher NAN flows. Expressed as a percentage of $\mathrm{N}$ intake, total NAN flow decreased linearly $(P<0.01)$ in response to higher $\mathrm{CP}$ supplementation, reflecting the more efficient capture of recycled $\mathrm{N}$ to the rumen at lower $\mathrm{N}$ intakes. Omasal flow of FAB
NAN (g/d) was not significantly affected, but PAB NAN flow increased linearly in response to dietary $\mathrm{CP}$, which resulted in a linear increase in the flow of total bacterial NAN. Expressed as a percentage of total bacterial NAN, PAB NAN flow also showed a positive linear response, whereas FAB NAN declined linearly. The flow of dietary NAN gave rise to linear and quadratic responses, increasing from $150 \mathrm{~g} / \mathrm{d}$ at $13.5 \% \mathrm{CP}$ to 177 and $213 \mathrm{~g} / \mathrm{d}$ at 15.0 and $16.5 \% \mathrm{CP}$, but with no further increments at 17.9 and $19.4 \%$ CP. Bacterial efficiency linearly increased in response to dietary CP. Omasal flows of neutral detergent insoluble N, ADIN (which was very low, averaging $4.5 \mathrm{~g} / \mathrm{d}$ across diets) and neutral detergent insoluble $\mathrm{N}$ - ADIN were not affected by diet.

In agreement with these results, NAN flow to the small intestine has been consistently shown to increase with dietary CP (Cunningham et al., 1996; Korhonen et al., 2002; Reynal et al., 2003). Usually, this is due to greater ruminal escape of dietary protein (Cunningham et al., 1996; Korhonen et al., 2002) because microbial NAN flow is not affected (Cunningham et al., 1996; Korhonen et al., 2002; Reynal et al., 2003). In the present study, the lack of difference in total NAN flow among the 3 highest $\mathrm{CP}$ diets indicated that all of the extra $\mathrm{N}$ intake from feeding diets with more than $16.5 \%$ CP did not result in greater MP supply.

Most of the total NAN in omasal digesta was of bacterial $(70 \%)$ rather than dietary $(30 \%)$ origin. Korhonen et al. (2002) and Reynal et al. (2003) also reported that, with feeding SSBM as the main protein supplement, flows of microbial NAN and dietary NAN were, respectively, 69 and $31 \%$, and 66 and 34\% of total NAN flow. These results emphasized the need for optimizing microbial formation in the rumen. The FAB NAN averaged $55 \%$, and PAB NAN $45 \%$, of total bacterial NAN flow. Similarly, Hristov and Broderick (1996) reported average flows of 52 and $48 \%$ for FAB NAN and PAB NAN, respectively. However, using the same microbial marker $\left({ }^{15} \mathrm{~N}\right)$ and similar techniques for omasal sampling and isolation of bacteria as the present study, Brito and Broderick (2004) and Reynal and Broderick (2005) reported data indicating that FAB NAN and PAB NAN represented, respectively, 45 and $55 \%$, and 43 and $57 \%$ of total bacterial NAN flow.

Low ruminal $\mathrm{NH}_{3}$ concentration may limit microbial growth (Sannes et al., 2002). In this trial (Olmos Colmenero and Broderick, 2006), diets with 13.5 and $15.0 \%$ $\mathrm{CP}$ resulted in ruminal $\mathrm{NH}_{3} \mathrm{~N}$ concentrations that were lower for a substantial portion of the day than the 5 $\mathrm{mg} / \mathrm{dL}$ recommended by Satter and Slyter (1974) for microbial growth. Those mean $\mathrm{NH}_{3} \mathrm{~N}$ levels were 3.0 $\mathrm{mg} / \mathrm{dL}$ from 8 to $24 \mathrm{~h}$ after feeding $(13.5 \% \mathrm{CP})$ and 3.7 $\mathrm{mg} / \mathrm{dL}$ from 12 to $24 \mathrm{~h}$ after feeding $(15.0 \% \mathrm{CP})$. KangMeznarich and Broderick (1980) found that, when add- 
Table 4. Effect of dietary $\mathrm{CP}$ content on $\mathrm{N}$ intake, ruminal protein degradation, and omasal flow of $\mathrm{N}$ fractions ${ }^{1}$

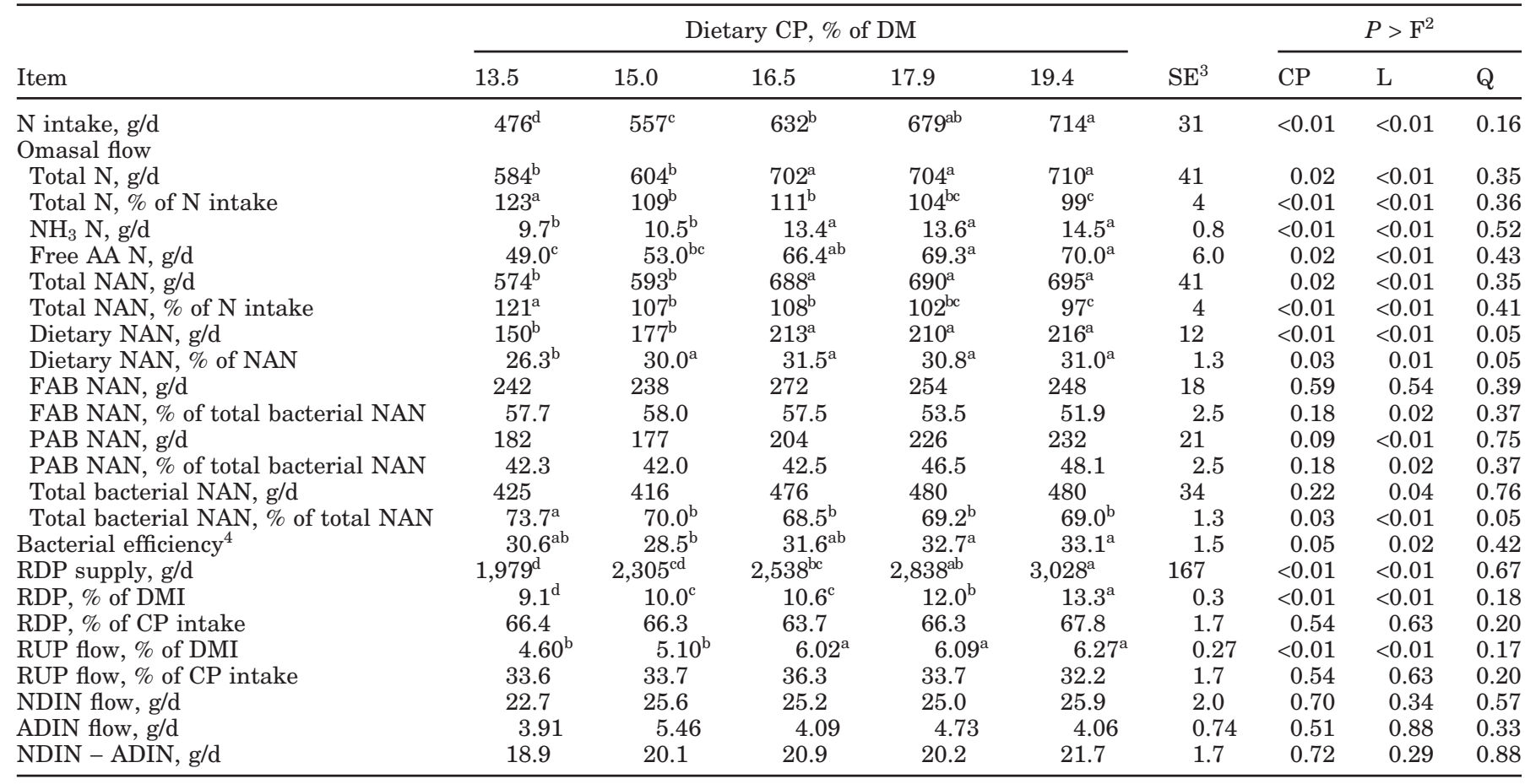

${ }^{\mathrm{a}-\mathrm{d}}$ Means in the same row without common superscripts differ $(P<0.05)$.

${ }^{1} \mathrm{FAB}=$ Fluid-associated bacteria, $\mathrm{PAB}=$ particle-associated bacteria.

${ }^{2}$ Probability of a significant effect of CP content or of a linear (L) or quadratic (Q) effect of dietary CP content.

${ }^{3}$ Standard error of the least squares means.

${ }^{4}$ Bacterial efficiency: $\mathrm{g}$ of bacterial NAN flow/kg of OM truly digested in the rumen.

ing incremental amounts of urea to a basal diet of corn and cottonseed hulls fed to nonlactating dairy cows, microbial protein synthesis was maximal with $8.5 \mathrm{mg} /$ $\mathrm{dL}$ of $\mathrm{NH}_{3} \mathrm{~N}$ in the rumen. Under this scenario, $\mathrm{NH}_{3}$ $\mathrm{N}$ was deficient from 4 to $24 \mathrm{~h}$ after feeding both 13.5 and $15.0 \% \mathrm{CP}$. These results may, at least partially, explain the numerically lower bacterial NAN flows for those diets compared with diets having $16.5 \%$ or more CP.

Although the amount of OM truly digested in the rumen was not significantly affected by diet, it increased numerically from $14.0 \mathrm{~kg} / \mathrm{d}$ at $13.5 \% \mathrm{CP}$ to 15.0 $\mathrm{kg} / \mathrm{d}$ at $16.5 \% \mathrm{CP}$, before declining to $14.3 \mathrm{~kg} / \mathrm{d}$ at $19.4 \%$ CP. The flow of total bacterial NAN also increased from 425 to $476 \mathrm{~g} / \mathrm{d}$ when dietary CP increased from 13.5 to $16.5 \%$, but remained similar $(480 \mathrm{~g} / \mathrm{d})$ when diets with 17.9 and $19.4 \% \mathrm{CP}$ were fed, resulting in the linear increase in microbial efficiency. Christensen et al. (1993), Cunningham et al. (1996), Korhonen et al. (2002), and Reynal et al. (2003) did not find any improvement in microbial efficiency by increasing the $\mathrm{CP}$ content of the diet. Low ruminal $\mathrm{pH}$ may impair $\mathrm{OM}$ digestion when fiber intake is too low. Diets fed in this trial averaged less than $23 \%$ NDF. However, except for
$8 \mathrm{~h}$ after feeding when $\mathrm{pH}$ was 5.9 on the diets with 15.0 and $16.5 \% \mathrm{CP}$, mean ruminal $\mathrm{pH}$ did not go below 6.0 in this trial (Olmos Colmenero and Broderick, 2006).

When expressed as a percentage of DMI, RDP supply increased linearly from $9.1 \%$ at $13.5 \%$ CP to $13.3 \%$ at $19.4 \% \mathrm{CP}$. These results were expected because the contribution of CP from SSBM, a highly degradable protein source (NRC, 2001; Reynal and Broderick, 2003), increased from 9 to $43 \%$ of total dietary CP. On the other hand, the proportion of total bacterial NAN in total NAN flow declined linearly from 74 to $69 \%$. This occurred because greater escape of dietary NAN in response to increasing SSBM diluted the contribution of bacterial NAN. Cunningham et al. (1996) also reported that the proportion of microbial NAN in total NAN flow fell from 72.8 to 65.1 and $53.4 \%$ when SSBM content of the diet increased from 9.85 to 11.0 and $14.6 \%$ of dietary DM. Stern et al. (1983) observed that the proportion of bacterial NAN in total NAN flow also declined from 53.9 to $41.9 \%$ when dietary $\mathrm{CP}$ content was increased from 13.1 to $22.9 \%$ by increasing corn gluten meal from 3.5 to $38.0 \%$ of dietary DM; however, bacterial NAN flow was not affected, implying that increased 
Table 5. Comparison of NRC (2001)-predicted RDP, RUP, and microbial CP flows with those measured using the omasal sampling technique ${ }^{1}$

\begin{tabular}{|c|c|c|c|c|c|c|}
\hline \multirow[b]{2}{*}{ Item } & \multicolumn{5}{|c|}{ Dietary CP, \% of DM } & \multirow[b]{2}{*}{ Average } \\
\hline & 13.5 & 15.0 & 16.5 & 17.9 & 19.4 & \\
\hline \multicolumn{7}{|l|}{ RDP supply, g/d } \\
\hline Measured & 1,979 & 2,305 & 2,538 & 2,838 & 3,028 & 2,538 \\
\hline Predicted & 2,103 & 2,317 & 2,629 & 2,756 & 3,023 & 2,566 \\
\hline Measured - predicted & -124 & -12 & -91 & 82 & 5 & -28 \\
\hline \multicolumn{7}{|l|}{ RUP, g/d } \\
\hline Measured & 998 & 1,171 & 1,413 & 1,399 & 1,440 & 1,284 \\
\hline Predicted & 967 & 1,125 & 1,347 & 1,459 & 1,604 & 1,300 \\
\hline Measured - predicted & 31 & 46 & 66 & -60 & -164 & -16 \\
\hline \multicolumn{7}{|l|}{ Bacterial CP, g/d } \\
\hline Measured & 2,655 & 2,601 & 2,973 & 2,997 & 2,998 & 2,845 \\
\hline Predicted & 1,787 & 1,947 & 2,031 & 1,973 & 2,012 & 1,950 \\
\hline Measured - predicted & 868 & 654 & 942 & 1,024 & 986 & 895 \\
\hline
\end{tabular}

${ }^{1}$ NRC-predicted values were computed based on actual composition of diets, actual BW and DMI, milk yield, and milk composition of each ruminally cannulated cow.

dietary NAN flow was responsible for diluting the bacterial NAN in total NAN flow.

Bacterial NAN flow, estimated from the amount of allantoin excreted in urine (reported in our companion paper; Olmos Colmenero and Broderick, 2006), reflected the linear increase measured for this variable using the omasal sampling and ${ }^{15} \mathrm{~N}$ as microbial marker. However, bacterial NAN flows estimated with the allantoin approach were on average $185 \mathrm{~g} / \mathrm{d}$ lower than omasal values. Reynal and Broderick (2005), feeding cows diets that contained 4 levels of RDP and using the same omasal methodology to estimate bacterial NAN flow, also found that urinary allantoin excretion underestimated bacterial flow by 120 to $170 \mathrm{~g} / \mathrm{d}$ compared with omasal measurements. However, they observed that both estimates of bacterial NAN flows yielded similar slopes when regressed on the observed RDP contents of the diet: 32.6 (urinary allantoin) and 35.4 (omasal sampling) $\mathrm{g} / \mathrm{d}$ for every percentage unit of dietary RDP. Although urinary excretion of allantoin underestimated bacterial NAN flow, these results indicated that the technique was sensitive to changes in bacterial NAN flow in response to dietary alteration.

Microbial CP flow, estimated with the NRC (2001) model using composition of the experimental diets and the production parameters of individual cows, was substantially lower than bacterial flows measured by omasal sampling (Table 5). Averages across all diets were 1,950 and 2,845 g/d, respectively. Moreover, RDP was overpredicted by the NRC (2001) model by 120,12 , and $91 \mathrm{~g} / \mathrm{d}$ for diets with $13.5,15.0$, and $16.5 \% \mathrm{CP}$, respectively, and underpredicted by 82 and $5 \mathrm{~g} / \mathrm{d}$ for diets with 17.9 and $19.4 \%$ CP. However, when averaged across diets, the NRC (2001) model overpredicted RDP by only $28 \mathrm{~g} / \mathrm{d}$. In contrast, NRC (2001) underpredicted RUP by 31, 46, and $66 \mathrm{~g} / \mathrm{d}$ for the 3 lower CP diets and overpredicted by 60 and $164 \mathrm{~g} / \mathrm{d}$ for the 2 higher CP diets. When averaged across all diets, RUP was overpredicted by only $16 \mathrm{~g} / \mathrm{d}$ using NRC (2001). These comparisons indicate that the NRC (2001) model requires improvement for accurate prediction of microbial CP flow. It also indicates that, for diets based on alfalfa silage, corn silage, rolled high-moisture shelled corn, and SSBM as the supplemental protein, the NRC (2001) overall predictions of RDP and RUP are apparently accurate.

\section{Optimal Dietary CP}

Regression coefficients as well as estimated optimal dietary CP concentrations for 8 of the variables that showed quadratic responses $(P \leq 0.10)$ to increasing levels of dietary CP are presented in Table 6 . The optima dietary CP ranged from 16.3 to $18.7 \%$ with an overall mean of $17.1 \%$. The optima for intake of DM, $\mathrm{OM}$, and NDF averaged $16.8 \% \mathrm{CP}$ and for the amount of $\mathrm{DM}$ and $\mathrm{OM}$ apparently digested in the rumen averaged $16.4 \% \mathrm{CP}$. The maximum for the 3 variables related to microbial and total NAN flow at the omasum averaged $18.0 \% \mathrm{CP}$.

\section{CONCLUSIONS}

Five levels of dietary CP were fed to dairy cows. Intake of DM, OM, and NDF, and amount of DM and OM digested in the rumen showed quadratic trends in response to CP. Digestion of NDF showed a linear trend, and amount of $\mathrm{ADF}$ digested in the rumen a linear response, with higher CP supplementation. Increasing $\mathrm{CP}$ of the diet also resulted in a linear increase in omasal flow of total NAN due to increases in both dietary NAN and total bacterial NAN flows. Although the qua- 
Table 6. Regression coefficients and optimal dietary CP concentrations for traits showing quadratic responses $(P \leq 0.10)$

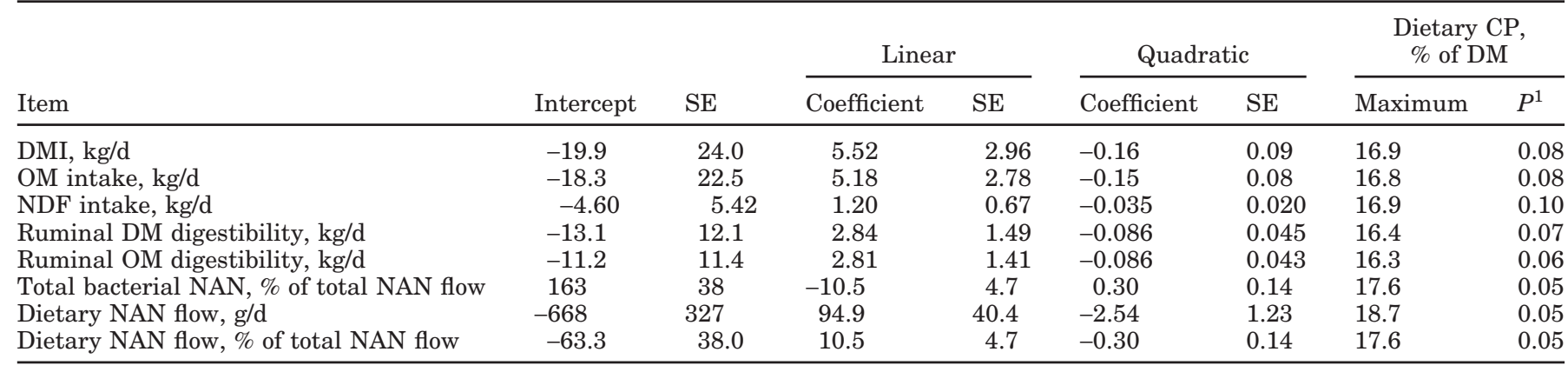

${ }^{1}$ Probability of quadratic effect of dietary CP content.

dratic maximum for the proportion of bacterial NAN in total NAN flow was observed at slightly higher dietary $\mathrm{CP}$, quantitative flow of bacterial and total NAN was not increased by feeding more than $16.5 \% \mathrm{CP}$. The results of this study also indicated that the NRC (2001) model might underpredict microbial protein flows. Feeding $16.5 \%$ dietary $\mathrm{CP}$ appeared to be adequate to promote maximal ruminal outflow of microbial and total NAN in dairy cows.

\section{ACKNOWLEDGMENTS}

The authors wish to thank the farm crew for harvesting and storing the feedstuffs used in this trial; Len Strozinski and the barn crew for feeding and animal care at the US Dairy Forage Center Research Farm (Prairie du Sac, WI); Santiago Reynal and Andre Brito for assisting with omasal sampling; Wendy Radloff, Mary Becker, and Fern Kanitz for assisting with laboratory analyses; and Peter Crump for aiding with statistical analyses. The first author also thanks Consejo Nacional de Ciencia y Tecnologia (CONACyT) Mexico, and Universidad de Guadalajara (Jalisco, Mexico) for partial financial support.

\section{REFERENCES}

AOAC. 1980. Official Methods of Analysis. 13th ed. Association of Official Analytical Chemists, Washington, DC.

Brito, A. F., and G. A. Broderick. 2004. Effects of different protein supplements on nitrogen utilization in dairy cows. II. Digesta flow and bacterial protein synthesis. J. Dairy Sci. 87(Suppl. 1):161. (Abstr.)

Broderick, G. A. 2003. Effects of varying dietary protein and energy levels on the production of lactating dairy cows. J. Dairy Sci. 86:1370-1381.

Broderick, G. A., and N. R. Merchen. 1992. Markers for quantifying microbial protein synthesis in the rumen. J. Dairy Sci. 75:2618-2632.

Broderick, G. A., P. Udén, M. L. Murphy, and A. Lapins. 2004. Sources of variation in rates of in vitro rumen protein degradation. J. Dairy Sci. 87:1345-1359.

Christensen, R. A., M. R. Cameron, T. H. Klusmeyer, J. P. Elliot, J. H. Clark, D. R. Nelson, and Y. Yu. 1993. Influence of amount and degradability of dietary protein on nitrogen utilization by dairy cows. J. Dairy Sci. 76:3497-3513.

Combs, D. K., and L. D. Satter. 1992. Determination of marker in digesta and feces by direct current plasma spectroscopy. J. Dairy Sci. 75:2176-2183.

Craig, W. M., D. R. Brown, G. A. Broderick, and D. B. Ricker. 1987. Post-prandial compositional changes of fluid-associated and particle-associated ruminal microorganisms. J. Anim. Sci. 65:1042-1048.

Cunningham, K. D., M. J. Cecava, T. R. Johnson, and P. A. Ludden. 1996. Influence of source and amount of dietary protein on milk yield by cows in early lactation. J. Dairy Sci. 79:620-630.

France, J., and R. C. Siddons. 1986. Determination of digesta flow by continuous marker infusion. J. Theor. Biol. 121:105-119.

Hintz, R. W., D. R. Mertens, and K. A. Albrecht. 1995. Effects of sodium sulfite on recovery and composition of detergent fiber and lignin. J. AOAC 78:16-22.

Hristov, A. N., and G. A. Broderick. 1996. Synthesis of microbial protein in ruminally cannulated cows fed alfalfa silage, alfalfa hay, or corn silage. J. Dairy Sci. 79:1627-1637.

Huhtanen, P., K. Kaustell, and S. Jaakkola. 1994. The use of internal markers to predict total digestibility and duodenal flow of nutrients in cattle given 6 different diets. Anim. Feed Sci. Technol. 48:211-227.

Huhtanen, P., and K. J. Shingfield. 2005. Grass silage: Factors affecting efficiency of $\mathrm{N}$ utilization in milk production. Pages $35-50$ in Silage Production and Utilisation, Proc. XIVth Int. Silage Conf., Belfast, UK. R. S. Park and M. D. Stronge, ed. Wageningen Academic Publ., Wageningen, The Netherlands.

Ipharraguerre, I. R., and J. H. Clark. 2005. Impacts of the source and amount of crude protein on the intestinal supply of nitrogen fractions and performance of dairy cows. J. Dairy Sci. 88(E Suppl.):E22-E37.

Kang-Meznarich, J. H., and G. A. Broderick. 1980. Effects of incremental urea supplementation on ruminal ammonia concentration and bacterial protein formation. J. Anim. Sci. 51:422-431.

Korhonen, M., A. Vanhatalo, and P. Huhtanen. 2002. Effect of protein source on amino acid supply, milk production, and metabolism of plasma nutrients in dairy cows fed grass silage. J. Dairy Sci. 85:3336-3351.

Leonardi, C., M. Stevenson, and L. E. Armentano. 2003. Effect of two levels of crude protein and methionine supplementation on performance of dairy cows. J. Dairy Sci. 86:4033-4042.

Martin, C., A. G. Williams, and D. B. Michalet. 1994. Isolation and characteristics of the protozoal and bacterial fractions from bovine ruminal contents. J. Anim. Sci. 72:2962-2968.

Misra, A. K., and S. S. Thakur. 2001. Effect of dietary supplementation of sodium salt of isobutyric acid on ruminal fermentation and nutrient utilization in a wheat straw based low protein diet fed to crossbred cattle. Asian-Australas. J. Anim. Sci. 14:479-484.

Nagel, S. A., and G. A. Broderick. 1992. Effect of formic acid or formaldehyde treatment of alfalfa silage on nutrient utilization by dairy cows. J. Dairy Sci. 75:140-154. 
National Research Council. 2001. Nutrient Requirements of Dairy Cows. 7th rev. ed. Natl. Acad. Sci., Washington, DC.

Olmos Colmenero, J. J., and G. A. Broderick. 2006. Effect of dietary crude protein concentration on milk production and nitrogen utilization in lactating dairy cows. J. Dairy Sci. 89:1704-1712.

Reynal, S. M., and G. A. Broderick. 2003. Effects of feeding dairy cows protein supplements of varying ruminal degradability. J. Dairy Sci. 86:835-843.

Reynal, S. M., and G. A. Broderick. 2005. Effect of dietary level of rumen-degraded protein on production and nitrogen metabolism in lactating dairy cows. J. Dairy Sci. 88:4045-4064.

Reynal, S. M., G. A. Broderick, S. Ahvenjarvi, and P. Huhtanen. 2003. Effect of feeding protein supplements of differing degradability on omasal flow of microbial and undegraded protein. J. Dairy Sci. 86:1292-1305.

Sannes, R. A., M. A. Messman, and D. B. Vagnoni. 2002. Form of rumen-degradable carbohydrate and nitrogen on microbial protein synthesis and protein efficiency of dairy cows. J. Dairy Sci. 85:900-908.

Santos, F. A. P., J. E. P. Santos, C. B. Theurer, and J. T. Huber. 1998. Effects of rumen-undegradable protein on dairy cow performance: A 12-year literature review. J. Dairy Sci. 81:3182-3213.
SAS Institute. 1999-2000. SAS/STAT User's Guide. Release 8.1. SAS Institute, Inc., Cary, NC.

Satter, L. D., and L. L. Slyter. 1974. Effect of ammonia concentration on rumen microbial protein production in vitro. Br. J. Nutr. $32: 199-208$

Siddons, R. C., J. Paradine, D. E. Beever, and P. R. Cornell. 1985. Ytterbium acetate as a particulate-phase digesta-flow marker. Br. J. Nutr. 54:509-520.

Stern, M. D., L. M. Rode, R. W. Prange, R. H. Stauffacher, and L. D. Satter. 1983. Ruminal protein degradation of corn gluten meal in lactating dairy cattle fitted with duodenal T-type cannulae. J. Anim. Sci. 56:194-205.

Stokes, S. R., W. H. Hoover, T. K. Miller, and R. Blauweikel. 1991. Ruminal digestion and microbial utilization of diets varying in type of carbohydrate and protein. J. Dairy Sci. 74:871-881.

Uden, P., P. E. Colucci, and S. P. J. Van. 1980. Investigation of chromium, cerium and cobalt as markers in digesta: Rate of passage studies. J. Sci. Food Agric. 31:625-632.

Van Soest, P. J., J. B. Robertson, and B. A. Lewis. 1991. Methods for dietary fiber, neutral detergent fiber and nonstarch polysaccharides in relation to animal nutrition. J. Dairy Sci. 74:35833597 . 